\title{
DECISION CRITERIA FOR OPTIMIZING POSTEMERGENCE JOHNSONGRASS CONTROL IN SOYBEAN CROPS IN ARGENTINA ${ }^{1}$
}

\author{
DANIEL TUESCA ${ }^{2}$, EDUARDO PURICELLI ${ }^{3}$, LUISANISENSOHN ${ }^{4}$, DELMA FACCIN ${ }^{4}$ and JUANPAPA ${ }^{5}$
}

\begin{abstract}
Field studies were established in Zavalla and Oliveros, Argentina, during four years in order to optimize Johnsongrass (Sorghum halepense (L.) Pers.) chemical control by means of the thermal calendar model in comparison with other criteria (weed height or days after sowing). The effect of three application dates of postemergence herbicides was determined by visual control, density of tillers originated from rhizome bud regrowth, and from crown and shoot bud regrowth, and soybean yield. Following the thermal calendar model criterion, applications during the second date afforded the best control. Weed height for the first date showed little variability between experiments but was highly variable in the second and third application dates, achieving in some cases values greater than $120 \mathrm{~cm}$. For all years, no significant differences were detected for crop yield between the first and second application dates, and yields were always lower for the third date. The greatest rhizome bud regrowth was observed for the earliest application date and the highest crown and shoot bud regrowth was determined for the last application date. Parameters associated with control efficiency showed the best behaviour for the second date. However, plant height at this moment may interfere with herbicide application and the variability exhibited by this parameter highlights the risk of determining control timing using only one decision criterion.
\end{abstract}

Index terms: weeds, herbicides, application timing.

\section{CRITÉRIOS DE DECISÃO PARA OTIMIZAR O CONTROLE DE CAPIM-MASSAMBARÁ EM CONDIÇÕES DE PÓS-EMERGÊNCIA NA CULTURA DA SOJA, NA ARGENTINA}

\begin{abstract}
RESUMO - Foram conduzidos experimentos de campo durante quatro anos agrícolas em Zavalla e Oliveros, Argentina, com o objetivo de otimizar o controle químico de capim-massambará (Sorghum halepense (L.) Pers.), usando o modelo do calendário térmico em comparação com outros critérios de decisão (altura da planta daninha ou dias após a semeadura). O efeito do herbicida foi determinado por avaliação visual, densidade de perfilhos originados de rebrota de rizomas e de touceira e caule, e rendimento de grão de soja. As aplicações segundo o critério do calendário térmico mostraram o melhor controle. A altura da planta daninha na primeira época evidenciou pouca variabilidade entre tratamentos, mas foi muito variável pela segunda e terceira época, atingindo, em alguns casos, valores maiores que $120 \mathrm{~cm}$. Os rendimentos da cultura na primeira e segunda época não diferiram entre si e superaram o rendimento da terceira época. A maior densidade de rebrota de rizomas foi observada na primeira época de aplicação, e o maior rebroto de touceira e caule foi determinado na terceira época. Os parâmetros associados com a eficiência mostraram o melhor comportamento na segunda época. Contudo, a altura da planta nesse momento pode interferir com a aplicação do herbicida e a variabilidade mostrada por esse parâmetro salienta o risco de determinar a época de controle usando só um critério de decisão.
\end{abstract}

Termos para indexação: planta daninha, herbicidas, época de aplicação.

${ }^{1}$ Accepted for publication on October 10, 1998.

${ }^{2}$ Lic. en Biol., Fac. Ciencias Agrarias, Univ. Nac. de Rosario. CC 14 (2123) Zavalla, Santa Fe, Argentina E-mail: dtuesca@agatha.unr.edu.ar

${ }^{3}$ Ing. Agr., M.Sc., Fac. Ciencias Agrarias, Univ. Nac. de Rosario. E-mail: epuricel@sede.unr.edu.ar

${ }^{4}$ Ing. Agr., Fac. Ciencias Agrarias, Univ. Nac. de Rosario. E-mail: lnisen@arnet.com.ar

${ }^{5}$ Ing. Agr, EEA INTA Oliveros, CC 4 (2206) Oliveros, Santa Fe, Argentina. E-mail: dfaccini@arnet.com.ar

\section{INTRODUCTION}

Johnsongrass (Sorghum halepense (L.) Pers.) is one of the world's worst weeds (Holm et al., 1977). This perennial weed can reproduce by both vegetative (rhizome) and sexual (seed) means (Horowitz, 1973). In Argentina, infestation of this weed is increasing, causing variable reductions in 
summer row crops yields. In soybeans, yield reductions caused by Johnsongrass interference has been documented by several authors (Banks \& Tripp, 1983; Williams \& Hayes, 1984; Leguizamón \& Vitta, 1989; Puricelli, 1993).

Inefficient control of Johnsongrass may determine regrowth from both rhizome or crown originating new shoots. These control failures may be associated with timing of application (Obrigawitch et al., 1990) and herbicide rates (Frans et al., 1991). Many foliage applied herbicides do not adequately control rhizome regrowth because insufficient quantities of the product reach the belowground tissues (Obrigawitch et al., 1990).

Postemergence herbicide applications for Johnsongrass are generally based on plant height (Ghersa et al., 1990; Eleftherohorinos \& Kotoula-Syka, 1995; Haitas et al., 1995; Steckel \& Defelice, 1995) and less often on number of days after sowing (DAS) (Kihara, 1989) and number of leaves (Mitidieri, 1983). Another decision criterion to determine optimum herbicide application timing is the thermal calendar model developed by Satorre \& Ghersa (1985). This model predicts the period during which rhizome biomass is at a minimum and the weed population is more susceptible to any control practice and relates the dynamics of belowground biomass with accumulated thermal units (A.T.U.).

The formula for calculating A.T.U. is:

A.T.U. $=\sum_{i=1}^{n}\left(t_{i}-15\right)^{\circ} \mathrm{C}$

when ti, the mean daily air temperature of each day up to day $\mathrm{n}$, is greater than $15^{\circ} \mathrm{C}$.
This critical stage is achieved with A.T.U. of 250-300 ${ }^{\circ} \mathrm{C}$.days after the last cultivation for oats, wheat and unsown areas or $230^{\circ} \mathrm{C}$.days for soybeans (Vitta \& Leguizamón, 1991).

This study considers different criteria to decide postemergence herbicide application time in soybean in order to optimize Johnsongrass control and to determine compatibility of such criteria with maximum yields.

\section{MATERIAL AND METHODS}

Field studies were established during 1990/91, 1991/92, 1992/93 and 1993/94 at Zavalla (lat. 33 01' S), Province of Santa Fe and in 1993/94 at Oliveros (lat. $32^{\circ} 33^{\prime} \mathrm{S}$ ), Province of Santa Fe (Argentina). Experiments were arranged in a randomized complete block design with four replications. Plot size was $3.5 \times 6 \mathrm{~m}$ and soybean was sown at $0.70 \mathrm{~m}$ between rows and 33 plants $/ \mathrm{m}$ in late November in all experiments. Soybean cultivars were Asgrow 6381 at Zavalla, and RA 587 at Oliveros. In all experiments Johnsongrass plant height was measured periodically sampling 25 plants in each plot.

Experiments to determine the effect of control timing on herbicide efficacy were conducted in 1990/91 and 1991/92 in Zavalla and in 1993/94 in Oliveros. Postemergence grass herbicides used were: haloxyfopmethyl (120 g a.i./ha) at Zavalla and fenoxaprop-P-methyl (110 and $66 \mathrm{~g}$ a.i./ha) at Oliveros. Herbicide application was performed before, during and after minimum rhizome biomass stage was achieved according to the model of Satorre et al. (1985) (Table 1). Maximum and minimum daily temperatures were obtained from meteorological stations located less than $700 \mathrm{~m}$ from the experimental sites. A non-treated control plot was included. All herbicides were applied with a $\mathrm{CO}_{2}$ pressurized backpack sprayer equipped with Teejet 8001 flat-fan nozzles tips delivering $170 \mathrm{~L} /$ ha with a pressure of $210 \mathrm{KPa}$.

Herbicide efficiency was evaluated as visual estimates of percent control 30 days after application (DAA). Additionally, density of tillers originated from rhizome bud regrowth (RBR) and from crown and shoot buds

TABLE 1. Application timing expressed in days after sowing (DAS) and in accumulated thermal units (A.T.U.).

\begin{tabular}{|c|c|c|c|c|c|c|c|c|c|c|}
\hline \multirow[t]{2}{*}{ Dates } & \multicolumn{2}{|c|}{$\begin{array}{c}1990 / 91 \\
\text { Zavalla }\end{array}$} & \multicolumn{2}{|c|}{$\begin{array}{l}\text { 1991/92 } \\
\text { Zavalla }\end{array}$} & \multicolumn{2}{|c|}{$\begin{array}{l}1992 / 93 \\
\text { Zavalla }\end{array}$} & \multicolumn{2}{|c|}{$\begin{array}{c}1993 / 94 \\
\text { Zavalla }\end{array}$} & \multicolumn{2}{|c|}{$\begin{array}{l}1993 / 94 \\
\text { Oliveros } \\
\end{array}$} \\
\hline & $\overline{\mathrm{DAS}}$ & A.T.U & DAS & A.T.U & DAS & A.T.U & $\overline{\text { DAS }}$ & A.T.U & DAS & A.T.U \\
\hline $1^{\circ}$ & 27 & 174 & 24 & 190 & 23 & 126 & 19 & 133 & 24 & 165 \\
\hline $2^{\circ}$ & 35 & 238 & 35 & 282 & 38 & 261 & 26 & 253 & 34 & 247 \\
\hline $3^{\circ}$ & 46 & 327 & 42 & 302 & 48 & 323 & 45 & 310 & 43 & 313 \\
\hline
\end{tabular}


regrowth (CSBR) at 30 DAA at Oliveros. Broadleaf and grassy annual weeds were suppressed by hand weeding. In 1990/91 and 1991/92 at Zavalla and 1993/94 at Oliveros, soybean yield was determined at crop maturity by hand harvesting $4 \mathrm{~m}$ from the two middle rows.

Visual estimates of percent control were transformed to arcsine of the square root and a square root transformation was used for density data in order to homogenize variance. An analysis of variance was performed when relevant, and means were separated using Tukey's test, at 0.05 level.

\section{RESULTS AND DISCUSSION}

Visual estimates of percent control are shown in Table 2. In 1990/91 controls around $80 \%$ were determined for all application dates. In 1991/92, herbicide applications during the first and second dates exhibited Johnsongrass controls greater than $92 \%$ and were significantly better than applications during the last date. In 1993/94 weed control was highest for the second application date. From these visual estimates it can be concluded that following the thermal calendar model criterion, applications during the second date afforded better or similar Johnsongrass control than the other dates.

The height of Johnsongrass plants for applications performed in the first date was in agreement with the application criterion based on weed height of $25-50 \mathrm{~cm}$ often used by extension

TABLE 2. Visual estimates (and SE) of percent control Johnsongrass for each date at $\mathbf{3 0}$ days after the application (DAA) ${ }^{1}$.

\begin{tabular}{cccc}
\hline Dates & $\begin{array}{c}1990 / 91 \\
\text { Zavalla }\end{array}$ & $\begin{array}{c}1991 / 92 \\
\text { Zavalla }\end{array}$ & $\begin{array}{c}1993 / 94 \\
\text { Oliveros }\end{array}$ \\
\hline $1^{\circ}$ & $82.8 \mathrm{a}(0.9)$ & $92.6 \mathrm{a}(1.3)$ & $83.3 \mathrm{~b}(1.6)$ \\
$2^{\mathrm{o}}$ & $80.6 \mathrm{a}(1.7)$ & $95.0 \mathrm{a}(1.8)$ & $97.3 \mathrm{a}(0.8)$ \\
$3^{\mathrm{o}}$ & $79.4 \mathrm{a}(1.6)$ & $59.0 \mathrm{~b}(1.4)$ & $85.0 \mathrm{~b}(1.1)$ \\
\hline & \multicolumn{3}{l}{ For each experiment, means followed by a common letter are not } \\
\multicolumn{3}{l}{ significantly different at 0.05 level in Tukey's test. }
\end{tabular}

specialists and was slightly greater than $15-30 \mathrm{~cm}$ height, recommended by Dow Chemical Company (1984).

In the first application date, for all experiments, height was significantly lower than the following dates (Table 3). For the second date, in 1991/92 at Zavalla, Johnsongrass plants interfered with application although this interference showed no effect on visual estimates of percent control at 30 DAA probably due to herbicide rates and application method employed. However, lower rates usually applied in commercial farming and current application technology could determine lower control. For the third date, in the same experiment, weed height could be associated not only with the forementioned interference in the application but with the observed crop yield reductions as well. Weed height for the first date showed little variability between experiments, while in the second and third application dates it was highly variable.

The criterion based on calendar days for herbicide determines that applications should be performed 25 to 40 DAS to optimize weed control (Kihara, 1989). In the present experiments, applications following this criterion would have been performed at the second date, but Johnsongrass tillers at this moment would be too high to meet weed height criterion.

For all years, no significant differences were detected for crop yield between the first and second application dates, and yields were always lower for the third date (Table 4). Yield reduction for the third date can be explained by weed presence in soybean crops for a period longer than $40 \mathrm{DAS}$. This result is in accord with other studies (Mitidieri, 1983; Williams \& Hayes, 1984), where lower soybean yields were observed when Johnsongrass control was performed after this period. Using the thermal calendar model criterion for deciding postemergence application timing, Vitta \& Leguizamón (1991) found no

TABLE 3. Weed height in $\mathrm{cm}$ (and SE) for the different application dates ${ }^{1}$.

\begin{tabular}{|c|c|c|c|c|c|}
\hline Dates & $\begin{array}{c}1990 / 91 \\
\text { Zavalla }\end{array}$ & $\begin{array}{r}1991 / 92 \\
\text { Zavalla }\end{array}$ & $\begin{array}{c}1992 / 93 \\
\text { Zavalla }\end{array}$ & $\begin{array}{c}\text { 1993/94 } \\
\text { Zavalla }\end{array}$ & $\begin{array}{l}1993 / 94 \\
\text { Oliveros }\end{array}$ \\
\hline $1^{\circ}$ & $39.3 b(1.0)$ & $32.8 \mathrm{c}(2.8)$ & $23.1 \mathrm{~b}(3.1)$ & $30.6 c(3.9)$ & $19.7 \mathrm{c}(1.3)$ \\
\hline $2^{\circ}$ & $73.5 \mathrm{a}(1.5)$ & $100.2 b(3.3)$ & $124.2 \mathrm{a}(5.9)$ & $73.2 b(2.5)$ & $40.3 b(2.9)$ \\
\hline $3^{\circ}$ & $72.6 a(0.9)$ & $126.4 \mathrm{a}(4.0)$ & $126.0 \mathrm{a}(3.4)$ & $102.2 \mathrm{a}(4.5)$ & $60.5 \mathrm{a}(1.8)$ \\
\hline
\end{tabular}


significant differences in soybean yield for the different application dates probably due to the fact that weed control was always performed before 30 DAS.

The level of tiller regrowth from rhizomes or crown buds may be associated with timing of herbicide application. At Oliveros (1993/94), regardless of application rates the greatest RBR density was observed for the earliest application date (Table 5). This could be attributed to the low tiller density present at this moment ( 9 tillers $/ \mathrm{m}^{2}$ ) which represents $11 \%$ of the total emerged tillers during crop season. This is due to the fact that at this moment, few rhizome buds had already sprouted. For the second and third application date RBR density was lower which can be associated with the high density of sprouted buds when control was performed. Tiller density for second and third application dates was 23 and 38 tillers $/ \mathrm{m}^{2}$ respectively, representing $28.2 \%$ and $42.0 \%$ of the total emerged tillers. These greater tiller densities favoured the reception of enough herbicide as to achieve adequate rhizome control, notwithstanding the fact that the percentages of total emerged tillers were lower than those registered by Satorre \& Ghersa (1985) (40-50\%) and Vitta \& Leguizamón (1991) (70\%).

TABLE 4. Soybean yield in $\mathrm{kg} / \mathrm{ha}$ (and SE) for each application date.

\begin{tabular}{|c|c|c|c|}
\hline Dates & $\begin{array}{c}\text { 1990/91 } \\
\text { Zavalla } \\
\end{array}$ & $\begin{array}{l}\text { 1991/92 } \\
\text { Zavalla }\end{array}$ & $\begin{array}{l}1993 / 94 \\
\text { Oliveros }\end{array}$ \\
\hline $1^{\circ}$ & $3745 \mathrm{a}(65.9)$ & $3385 \mathrm{a}(85.8)$ & $2846 \mathrm{a}(49.0)$ \\
\hline $2^{\circ}$ & $3641 \mathrm{a}(34.8)$ & $3020 \mathrm{a}(96.7)$ & $2859 \mathrm{a}(58.6)$ \\
\hline $3^{\circ}$ & $2731 \mathrm{~b}(45.9)$ & $2127 \mathrm{~b}(67.0)$ & $2527 \mathrm{~b}(65.0)$ \\
\hline
\end{tabular}

TABLE 5. Rhizome bud regrowth (RBR) and crown and shoot buds regrowth (CSBR) in tillers $/ \mathrm{m}^{2}$ (and $\mathrm{SE}$ ) for each application dates and for both herbicide rates at Oliveros $^{1}$.

\begin{tabular}{|c|c|c|c|c|}
\hline \multirow[t]{2}{*}{ Dates } & \multicolumn{2}{|c|}{ RBR } & \multicolumn{2}{|c|}{ CSBR } \\
\hline & Rate 1 & Rate 2 & Rate 1 & Rate 2 \\
\hline $1^{\circ}$ & $4.8 \mathrm{a}(0.7)$ & $3.9 \mathrm{a}(0.1)$ & $1.4 \mathrm{~b}(0.4)$ & $1.1 \mathrm{~b}(0.2)$ \\
\hline $2^{\circ}$ & $1.2 \mathrm{~b}(0.5)$ & $2.6 \mathrm{~b}(0.3)$ & $0.8 \mathrm{~b}(0.2)$ & $0.7 \mathrm{~b}(0.1)$ \\
\hline $3^{\circ}$ & $0.6 \mathrm{~b}(0.8)$ & $1.1 \mathrm{~b}(0.5)$ & $6.7 \mathrm{a}(0.6)$ & $9.5 \mathrm{a}(0.5)$ \\
\hline
\end{tabular}

Pesq. agropec. bras., Brasília, v.34, n.5, p.749-753, maio 1999
For both rates, the highest CSBR was observed for the last application date probably because these buds increase their number as the growing season progresses. For the first and second date, CSBR showed very low values and did not differ significantly between treatments (Table 5). Thus, only applications during the second date result in minimization of both, RBR and CSBR.

Studies testing the thermal calendar model have been conducted in unsown areas (Ghersa et al., 1990) or annual crops as soybean (Vitta \& Leguizamón, 1991) and sunflower and soybean (Van Esso \& Ghersa, 1993). Few studies to our knowledge, have considered simultaneously, optimization of Johnsongrass control and the attainment of maximum crop yields.

Weed management programs using postemergence grass herbicides for controlling rhizome Johnsongrass must be flexible enough for allowing the producer in making decisions. Considering all results of the present work, parameters associated with control efficiency show the best behaviour for the second date. However, plant height at this moment may interfere with herbicide application and the variability exhibited by this parameter highlights the risk of determining control timing using only one decision criteria.

\section{CONCLUSIONS}

1. Following the thermal calendar model criterion, applications during the second date afford the best control.

2. Crop yield is the same for the first and second application dates, and yields are lower for the third date.

3. The greatest rhizome bud regrowth is observed for the earliest application date, and the highest crown and shoot bud regrowth is determined for the last application date.

4. Plant height for the second and third dates is highly variable and may interfere with herbicide application.

\section{REFERENCES}

BANKS, P.A.; TRIPP, T.N. Control of Johnsongrass (Sorghum halepense) in soybeans (Glycine max) with 
foliar-applied herbicides. Weed Science, v.31, p.628 633, 1983.

DOW CHEMICAL COMPANY. Herbicida Galant. Biokemia, v.36, p.1-11, 1984.

ELEFTHEROHORINOS, I.G.; KOTOULA-SYKA, E. Influence of herbicide application rate and timings for post-emergence control of Sorghum halepense (L.) Pers. in maize. Weed Research, v.35, p.99-103, 1995.

FRANS, R.E.; McCLELLAND, M.R.; HORTON, D.K.; CORBIN JUNIOR, B.R.; TALBERT, R.E. Crop and herbicide rotations for Johnsongrass (Sorghum halepense) control. Weed Science, v.39, p.660-666, 1991.

GHERSA, C.M.; SATORRE, E.H.; VAN ESSO, M.L.; PATARO, A.; ELIZAGARAY, R. The use of thermal calendar models to improve the efficiency of herbicide applications in Sorghum halepense (L.) Pers. Weed Research, v.30, p.156-160, 1990.

HAITAS, V.C.; KOTOULA-SYKA, E.; ELEFTHEROHORINOS, I.G. Influence of propaquizafop application rate and time on Sorghum halepense (L.) Pers. control and cotton (Gossypium hirsutum) yield. Weed Research, v.35, p.1-6, 1995.

HOLM, L.G.; PLUCKNETT, D.L.; PANCHO, J.V.; HERBERGER, J.P. The World'worst weeds, distribution and biology. Honolulu: Univ. of Hawaii, 1977. p.54-61.

HOROWITZ, M. Spatial growth of Sorghum halepense (L.) Pers. Weed Research, v.13, p.200-208, 1973.

KIHARA, R. El uso de graminicidas en soja en los últimos años. In: WORLD SOYBEAN RESEARCH CONFERENCE, 4., 1989. Proceedings... Buenos Aires, Argentina, 1989. p.1645-1656.

LEGUIZAMÓN, E.S.; VITTA, J.I. Análisis de la función de daño por sorgo de Alepo (Sorghum halepense (L.) Pers.) en soja (Glycine $\max ($ L.) Merr.). In: WORLD SOYBEAN RESEARCH CONFERENCE, 4., 1989. Proceedings... Buenos Aires, Argentina, 1989. p.1632-1638
MITIDIERI, A. El sorgo de Alepo, importancia, biología y aspectos básicos para su control. Panel de expertos: ecología y control de malezas perennes. Santiago de Chile: 1983. p.1-43.

OBRIGAWITCH, T.T.; KENION, W.H.; KURATLE, H. Effect of application timing on rhizome Johnsongrass (Sorghum halepense) control with DPX-V9360. Weed Science, v.38, p.45-49, 1990

PURICELLI, E. Influencia del espaciamiento entre filas y de la competencia de sorgo de Alepo sobre el rendimiento en soja tardía. Pesquisa Agropecuária Brasileira, v.28, n.11, p.1319-1326, 1993.

SATORRE, E.H.; GHERSA, C.M. Bases ecológicas para el manejo de la población de rizomas de sorgo de Alepo. Un método para predecir los cambios ciclicos de la biomasa de rizomas a partir de datos meteorológicos. Revista Tecnicrea, v.3, p.1-5, 1985.

SATORRE, E.H.; GHERSA, C.M.; PATARO, A.M. Prediction of Sorghum halepense (L.) Pers. rhizome sprout emergence in relation to air temperature. Weed Research, v.25, p.103-109, 1985.

STECKEL, G.J.; DEFELICE, M.S. Reducing Johnsongrass (Sorghum halepense) interference in corn (Zea mays) with herbicides and cultivation. Weed Technology, v.9, p.53-57, 1995.

VAN ESSO, M.L.; GHERSA, C.M. Improving Johnsongrass (Sorghum halepense) control in soybean and sunflower cropping systems. Weed Science, v.41, p.107-113, 1993.

VITTA, J.L.; LEGUIZAMÓN, E.S. Dynamics and control of Sorghum halepense (L.) Pers. shoot populations: a test of a thermal calendar model. Weed Research, v.31, p.73-79, 1991

WILLIAMS, C.S.; HAYES, R.M. Johnsongrass (Sorghum halepense) competition in soybean (Glycine max). Weed Science, v.32, p.498-501, 1984. 